\title{
Investigations on rock drillability applied to underground mine development vis-à-vis drill selection
}

\author{
BNV Siva Prasad \\ National Institute of Rock Mechanics \\ Bengaluru, India \\ sivaprasadbnv@yahoo.in
}

\author{
VMSR Murthy \\ Department of Mining Engineering \\ IIT(ISM) Dhanbad, India \\ vmsr_murthy@yahoo.com
}

\author{
SK Pandey \\ Rock Mechanics, Zawar Mines, HZL \\ s_k_pande@yahoo.co.in
}

\begin{abstract}
Current underground mining scenario is inclining towards mechanized drilling and blasting since it proves advantageous in many ways like controlled excavation profile, limited ground vibrations and better ground control, higher rates of advance, enhanced mine development rates besides maintaining a balance in overall economics of the project. Considering the challenges posed by varied geological conditionsencountered in mining and civil engineering excavations, application of mechanized drilling and blasting technique still dominates. In order to meet the existing mineral demands, the development rates need to be maximized. To attain such development rates, there is an increased drill requirement which calls for an uninterrupted, consistent and a reliable drill system in place.Drilling is further affected by uncontrollable parameters like geological properties, rock structure and in-situ stresses, and controllable parameters like thrust, rpm, feed, flushing, operator's skill, working conditions, etc.
\end{abstract}

Different rock drillability models have been reviewed in this paper to understand the influence of various key parameters influencing drill rates. However, it is interesting to note that not many of the drillability models consider the geology, rock drillability, machine (design and operational), bit parameters, in-situ stresses and working conditions all together. A case study of an underground hard rock mine is presented describing a mechanized drilling system for a development heading with a dimension of $3.6 \mathrm{~m}$ in width and $3.0 \mathrm{~m}$ in height using a rotary percussive electro-hydraulic drill jumbo. In order to meet a development rate of 3,600 meters per annum in a single mine, drill bits alone costs around Rs. 31.5 Lacs apart from other drilling expenses which is in fact a huge capital investment for any industry. This stresses on detailed research in this area and development of a comprehensive generalized model accounting for the key influencing variables.

Keywords-Rock Drillability Models, Drill Penetration Rate, Underground Development Heading, Small to Medium Diameter Drill, Case Study

\section{INTRODUCTION}

World's contiuous consumption of metal demands uninterrupted supply of ore from the mining industries. These demands are met from surface and underground metal mines byincreasingproduction. In order to sustain in world market, mine development rates need to be increased. Underground mine development is carried out using mechanized drill and blast system in which drilling forms the first and foremost component. Drill Penetration Rate (DPR) is a measure of rock drillability that definesrate of penetration of drill bit into the rock measured in $\mathrm{m} / \mathrm{s}$ or $\mathrm{m} / \mathrm{h}$. It is affected by Uncontrollable parameters likegeomechanical properties and rock structure \&Controllable parameters like drill design, operational parameters, working conditions and operator's skill. The parameters influencing the drill penetration rate are shown in Fig. 1.

These parameters are accounted for the estimation of the performance of the drilling equipment during planning of rock excavations.Properties such as geology are determined primarily by their origin of formation, mineral composition and rock discontinuities whereas the strength of the rock is measured in terms of its mechanical properties, viz. Strength, Deformability, Hardness, Fracture Toughness, Coefficients of friction, Crushability, Millability, and Abrasivity.

Drillability is tested by using several methods as given below [10]:

- Compiled historic performance data for a given drilling equipment and tool combination by referencing net penetration rates to results obtained in a standard rock type as a means of rating rock drillability.

- Compiled historic performance data including the utilized power levels for a given drilling equipment and tool combination relating the specific drilling energy to mechanical properties of rock as a means of rating rock drillability. Most commonly used mechanical properties are Uniaxial compressive strength, Brazilian Tensile Strength and Point Load Index.

- Stamp tests based on impact loading and crushing of a confined solid or aggregated specimen of intact rock. Drilling Rate Index, Siever's J and S-20 value, 


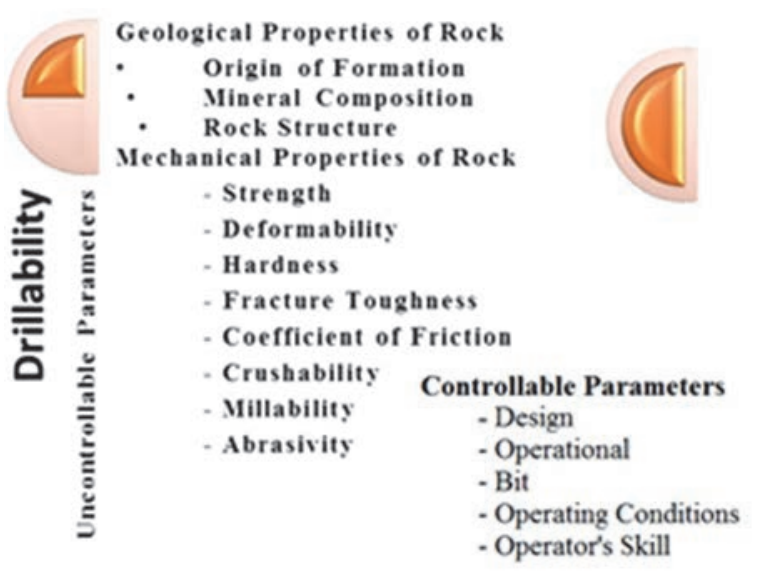

Parameters influencing rock drillability

Protodyakonov Rock Hardness, Rock Impact Hardness Number, Cerchar's Hardness Index and Cerchar's Abrasivity Index are most commonly used.

- Numerical simulation with finite element and particle flow codes.

- Analysis and simulation of stress wave propagation with bit indentation tests to incorporate the dynamic nature of rock loading and bit indentation encountered in percussive drilling.

\section{DRILLABILITY MODELS}

Many researchers studied the influence of intact rock, rockmass, mechanical and drillability properties of rocks, machine, operational and bit parameters on drill penetration rate by establishing relations that are valid under a specified set of conditions. Different methods of analysis wereadopted to correlate drill penetration rates with the influencing parameters and establish predictor equations. The relations so developed during such studies are referred to as Drillability Models. These models help in assessing and forecasting the effect of varying key influencing parameters on drill penetration rate allowingfor a timely modification of the drill system to an extent so as to carry out drilling without hampering the required drilling rate.

Some of the studies carried out related to underground drilling are presented below:

S. Kahraman et al $[1,13]$ have developed drillability predictor model using Tensile strength, Impact strength, Schmidt hammer's rebound number, Impact Strength Index, applicable only for $38.1 \mathrm{~mm}$ diameter cross bits and $76-89$ $\mathrm{mm}$ diameter button bits[14].

T. N. Singh et al [2] have predicted the drillability of rocks and wear factor using engineering properties of rocks demonstrating the applicability of cognitive systems or neural networks testing different rocks for Protodyakonov index, impact strength index, shore hardness number, Schmidt rebound hammer number, drillability and micro bit chisels for wear factor.
S.H. Hoseinie et al [3] have proposed a classification system to assess rock mass drillability index (RDi) using physical models so as to investigate the effect of joint characteristics on drilling rate and developed predictor equations using Joint spacing, Joint filling and Joint dip, applicable only for $37-42 \mathrm{~mm}$ jackhammer, and electro hydraulic percussive drills using button bits.

A. Bhatnagar and ManojKhandelwal [4] have developed a predictor model which aids in estimating the rate of penetration in rocks by incorporating thrust, revolutions per minute, flushing media and rock compressive strength into study.

Babatunde Adebayo et. al. [5] have selected rocks that were classified as very high compressive strength. The drillability characteristics of the rocks vary from extremely low to low drillability based on the Drilling Rate Index (DRI) and the drill bit life range from very low to extremely low life span. Uniaxial compressive strength, Tensile strength, Hardness, Drilling Rate Index, Schmidt hammer and miniature drill values are used for developing the model.

OlgayYarali and SairKahraman[6] assessed rock drillability using varied values of brittleness and developed predictor equations while V.C. Kelessidis in the same year predicted rock drillability from in-situ unconfined compressive strength of rock using the concept of specific energy.

Filip Dahl, et. al.[7] discussed about the classifications of the NTNU / SINTEF drillability test methods based on nearly 3200 samples originating from projects in 50 countries.

Suraj Kumar and VMSR Murthy [8]analyzed the performance of three rotary blasthole drills drilling through sandstone, shaly sandstone and hard sandstone based on Field and laboratory studies. They have calculated the Field Penetration Rate from the study and determined Cerchar's Hardness Index and used miniature drill values for developing an empirical model applicable for Tricone bits in rotary drilling.

Mohammad Javad et. al [9] have experimentally evaluated hardness models by drillability tests for carbonate rocks for $53.9 \mathrm{~mm}$ diameter rotary drills.

Though researchers have put in efforts in predicting and estimating drilling rates but no model has actually incorporated all the key influencing parameters.Thus a comprehensive study is required incorporating all such parameters for a practical estimate of drilling.

\section{CASE Study}

In India, drill jumbos are used extensively for development of drives, drifts, levels, haulages, accesses, stopes and galleries in underground hard rock mines. Rotary drilling and percussive drilling have proven to be very good in their respective field of applications.However, rotary percussive drilling allows to drill in varied rockmass conditions with a higher penetration depth per blow. Hence 
Drill Jumbos with rotary percussive drilling mechanism are gaining importance.

\section{A. Mining System}

Underground metal mining production comes from'Stopes; which are interconnected with drives (haulage and ore), drifts andlevels (drill, sub and trough) for having an easy access to ore. For a timely development of a stope to meet the required mineral targets, there must be a timely development of such access drives. A case study presented in this section comprises of level and drive development in an underground hard rock Lead-Zinc mine using single boom rotary-percussive electro-hydraulic drill jumbo.

Mining of ore is carried by sub level open stoping method in which different levels are developed at different vertical intervals in a stope well defined by boundary. The top most level forms the drill level drilling below the drive and the bottom most, ore drawing level is called Tough level. Development of both these levels initiates production drilling to commence. Subsequently, blasting activities commence leading to production of broken ore which is transferred to surface through dumpers, belt conveyors, skips, locos, etc.

\section{B. Geo-mining Conditions}

For development of drives, drilling is carried out in a host rock of dry, competent siliceous dolomite with good Rock Quality Designation (RQD) cut by two tightly healed rough or irregular, planar joint sets originated in a medium stressed environment. The rock is drilled at a vertical depth of $480 \mathrm{~m}$ from surface. Geo-mechanical properties of the intact rock are determined in the laboratory using rock core specimens and rockmass properties are estimated from RocLab software, as presented in Table I.

\section{Drilling System}

Drives with a dimension of $3.6 \mathrm{~m}$ in width and $3.0 \mathrm{~m}$ in height are developed using a 440 -volt single boom electrohydraulic drill jumbo in an underground mine. The drill equipment operates on electricity and hydraulics. Drilling is carried out using rotary-percussive system with feed keeping the rock tools and the drill string in contact with the rock at the bottom of the drill hole. The rock drill is attached to a shank adaptor which couples the drill rod to it. The mechanical energy transfer to rockis done from drill equipment through rock tools, i.e. Drill Bit. This exerts pressure at the bottom of the drill hole. Once the dynamic strength of the rock is overcome by the dynamic load applied by the drill bit on it, small rock chips off thereby allowing for penetration of drill bit into it [11].The technical specifications of the drill machine deployed are given in Table II.

The entire drill system has an important role to play in maintaining a consistent drill penetration rate. Drill bit parameters and bit wear also have an immense influence on it. The type of bit, flushing media, bailing speed, chip size, bit matrix and button pattern on a drill bit face, all together determine the efficiency of the drill system [12]. The machine parameters measured in the field during performance analysis of the drill machine are listed in Table
III. The parameters are adjusted as per the rockmass conditions to achieve the required penetration rate based on driller's experience with the rock and operator's skill, type of rock tools used, etc.Around 45 holes of 2.7-meter length are drilled per round of blast totaling to $121.5 \mathrm{~m}$ of drilling. A development rate of 3600 meters per annum is required to produce 0.36 million tons of ore by drilling at least $1,80,000$ meters of jumbo drilling per month with $90 \%$ advance per blast. At an observed drilling rate of $86.4 \mathrm{~m} / \mathrm{h}$, total percussion hours required per annum would be 2853.6 hours, considering a machine performance factor of $73 \%$. However, with a machine availability of $80 \%$, the drill machine now requires 3567.0 percussion hours per annum (PHPA), which means an additional 713.4PHPA is required to drill the same length.

TABLE I. INTACT ROCK AND ROCKMASS PROPERTIES

\begin{tabular}{|l|l|l|}
\hline \multicolumn{1}{|c|}{ Parameter } & \multicolumn{1}{c|}{ Unit } & \multicolumn{1}{c|}{ Value } \\
\hline Uniaxial Compressive Strength, $\sigma \mathrm{c}$ & $\mathrm{MPa}$ & 111 \\
\hline Rock Mass Rating, RMR & & 74 \\
\hline Young's Modulus of intact rock, Ei & $\mathrm{GPa}$ & 48 \\
\hline Poissons Ratio, $v$ & & 0.25 \\
\hline Rock Density, $\rho$ & $\mathrm{kg} / \mathrm{m} 3$ & 3054 \\
\hline Rockmass compressive strength, $\sigma_{\mathrm{cm}}$ & $\mathrm{MPa}$ & 37.4 \\
\hline Rockmass Young's modulus, Erm & $\mathrm{GPa}$ & 38.6 \\
\hline
\end{tabular}

TABLE II. TECHNICAL SPECIFICATIONS OF THE DRILL SySTEM

\begin{tabular}{|l|l|}
\hline \multicolumn{1}{|c|}{ Particulars } & \multicolumn{1}{c|}{ Value } \\
\hline Machine Type & Single Boom Drill Jumbo \\
\hline Operation Type & Electro-hydraulic \\
\hline Weight of Rock Drill & $130 \mathrm{~kg}$ \\
\hline Impact Frequency & $59 \mathrm{~Hz}$ \\
\hline Percussion Pressure & $120-175 \mathrm{bar}$ \\
\hline Impact Power & $11-16 \mathrm{~kW}$ \\
\hline Feed Force, max & $25 \mathrm{kN}$. \\
\hline Net Feed Weight & $500 \mathrm{~kg}$ \\
\hline Water Flushing Capacity & $301 / \mathrm{min}$ at $11 \mathrm{bar}$ \\
\hline Minimum Water Supply Pressure & $2 \mathrm{bar}$ \\
\hline Rotation & $135-240 \mathrm{rpm}$ \\
\hline Drill Length & $2.7 \mathrm{~m}$ \\
\hline
\end{tabular}

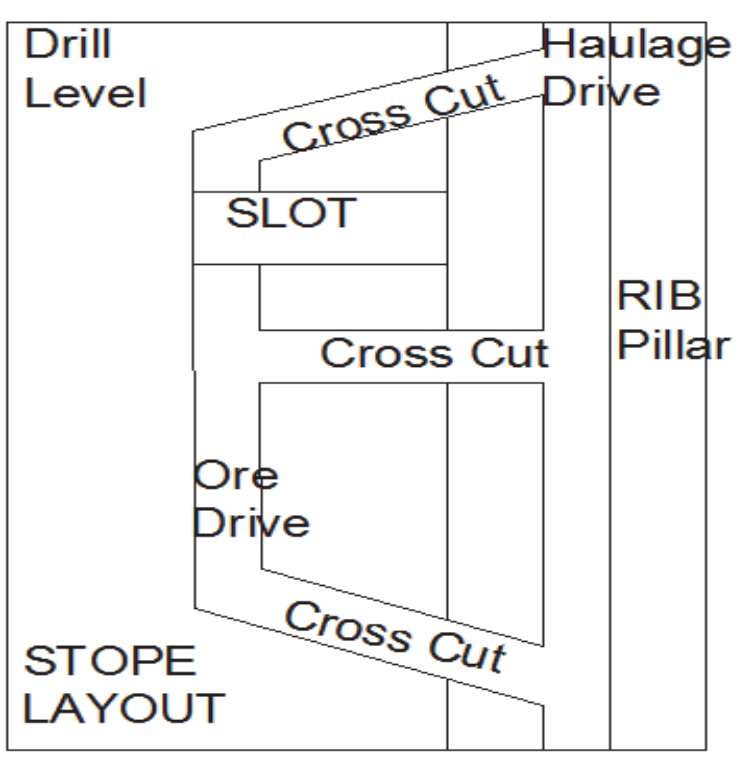

Fig. 2. Mining and Stoping Layout - Drill Level 
TABLE III. MAChINE PARAMETERS For PERFormanCE ANALYSIS

\begin{tabular}{|c|c|c|c|}
\hline Parameter & Value & Parameter & Valu \\
\hline $\mathrm{Tc}$ & 22.8 & $\mathrm{Wd}$ & 0.8 \\
\hline $\mathrm{Pc}$ & 7.6 & $\mathrm{Fd}$ & 10.5 \\
\hline $\mathrm{Rc}$ & 2.5 & $\mathrm{PH}$ & 118.3 \\
\hline $\mathrm{Wc}$ & 0.8 & BW & 300 \\
\hline$\overline{F c}$ & 3.9 & $\mathrm{BD}$ & 39 \\
\hline $\mathrm{Td}$ & 95.5 & $\mathrm{Ld}$ & 2.7 \\
\hline $\mathrm{Pd}$ & 13.4 & $\overline{D P R}$ & 86.4 \\
\hline $\mathrm{Rd}$ & 3.4 & & \\
\hline $\begin{array}{l}\text { Legends } \\
\text { Time for Collarin } \\
\text { Percussion Press } \\
\text { Pc, MPa. } \\
\text { Rotation Pressur } \\
\text { MPa. } \\
\text { Water Pressure } \\
\text { MPa. } \\
\text { Feed Pressure } \\
\text { MPa. } \\
\text { Time for Drillin } \\
\text { Td, sec. } \\
\text { Percussion Press } \\
\text { full percussion, } \mathrm{P} \\
\text { Rotation Pressure } \\
\text { percussion, Rd, }\end{array}$ & $\begin{array}{l}\text { sec. } \\
\text { vhile collaring, } \\
\text { e collaring, Rc, } \\
\text { collaring, Wc, } \\
\text { collaring, Fc, } \\
\text { full Percussion, } \\
\text { hile drilling in } \\
\text { a. drilling in full }\end{array}$ & $\begin{array}{l}\text { Water Pressu } \\
\text { full percussio } \\
\text { Feed Pressur } \\
\text { full percussio } \\
\text { Percussion Ho } \\
\text { Bit Wear, BW } \\
\text { Bit Diameter, } \\
\text { Drillhole Len } \\
\text { Drill Penetra } \\
\mathrm{m} / \mathrm{h} \text {. }\end{array}$ & $\begin{array}{l}\text { e drillin } \\
\text { MPa. } \\
\text { drilling } \\
\text { MPa. } \\
\text { H, sec. } \\
\text { m. } \\
\text { m. } \\
\text { Rate, D }\end{array}$ \\
\hline
\end{tabular}

Fig. 3. Jumbo drilling in an underground hard rock mine

This results in loss of productivity. At a rate of around Rs. 1470 per cubic meter of rock drilling, blasting and mucking, the total cost involved is Rs. 15,43,14,720 per annum for $3600 \mathrm{~m}$ of mine development per annum which is really a huge capital investment. Hence, productivity of drill equipment is much more important than the bit price per meter of drilling for a mining industry. Button bits coupled with the drill rods helps in transfer of mechanical energy from the drill equipment to the rockmass. This energy transfer in turns depends on the impact energy and bit wear. Each bit lasts typically for $200 \mathrm{~m}$ drill length. At such a rate of bit wear, around 900 bits per annum would be required in inventory to meet the desired development rate. Each bit costing around Rs. 3,500 totaling to Rs. 31,50,000 per annum, which accounts for drill bits alone apart from other drilling expenses. This calls for strategic drill inventory management for a consistent machine performance.

Typical drilling and Stoping layout is shown in Figure 2 and drilling in underground hard rock mine by electrohydraulic drill jumbo during mine development is shown in Fig. 3. The competent rockmass and the rock structure shown in the Figure provides an insight into the nature of rockmass and its influence on drillability. In spite of all the best technology provided by the mine, it's the driller's capability and skill that controls the drill performance finally.

\section{INFERENCES}

As per the field observations, for an advance of 3,600 m linear development, the required drilling length is $1,80,000$ $\mathrm{m}$ per annum. Current development rate achieved is only 2640 mper month. This calls for optimizing the drill operating variables for the range of rock conditions encountered. The drillability assessment of rock and drill performance analysis can also help select a suitable machine if needed. This gap in drilling, results in lag in mine development thereby, resulting in untimely approach to stopes which affects mine production schedule. Productivity of drill equipment is much more important than the bit price per meter of drilling. Lower percussion hours for drilling a single drill hole yields higher productivity than a drill which takes more time in drilling the same length thereby increasing the total percussion hours. Any increment in drilling time, i.e. percussion hours increases overall drilling cost due to low productivity of the equipment.Therefore, the drilling system needs to be optimized to maintain a balance in overall economy of the project. This also suggests that a comprehensive study to develop a generalized model for predicting drill penetration rate incorporating rockmass, geo-mechanical, drillability, machine, design, operational and bit parameters is the need of the hour for rational selection and optimization of underground drills.

\section{ACKNOWLEDGMENT}

I am very much obliged to National Institute of Rock Mechanics (NIRM) for allowing me to carry out the research and the Mine Management for allowing me to conduct studies. This forms the part of $\mathrm{PhD}$ work being accomplished by the first author at Indian School of Mines, Dhanbad.

\section{REFERENCES}

[1] S. Kahraman, N. Bilgin, and C. Feridunoglu, "Dominant rock properties affecting the penetration rate of percussive drills," International journal of rock mechanics \& mining sciences, vol. 40,pp.711-723, 2003.

[2] T.N. Singh, A.R. Gupta, and R. Sain, "A comparative analysis of cognitive systems for the prediction of drillability of rocks and wear factor," Geotechnical and geological engineering, vol. 24 issue 2, pp. 299-312, 2006.

[3] S.H. Hoseinie, H. Aghababaei, and Y. Pourrahimian, "Development of a new classification system for assessing of rock mass drillability index (RDi)," International journal of rock mechanics \& mining science, vol. 45, pp. 1-10, 2008. 
[4] A. Bhatnagar,andM. Khandelwal, "An intelligent approach to evaluate drilling performance, neural computing and applications," Springer Publications (Online Published), 2010.

[5] A. Babatunde, Z.O. Opafunso, and J.A. Akande, "Drillability and strength characteristics of selected rocks in Nigeria," AU journal of technology, vol. 14 issue 1, pp. 56-60, 2010.

[6] Y. Olgay, and S. Kahraman, "The drillability assessment of rocks using the different brittleness values," Tunneling and underground space technology, vol. 26, pp. 406-414, 2011.

[7] F.E.B. Dahl, A. Bruland, P.D. Jakobsen, B. Nilsen, and E. Grøv, "Classifications of properties influencing the drillability of rocks, based on the NTNU/SINTEF test method," Tunnelling and Underground Space Technology, vol. 28, 2012.

[8] S. Kumar, V.M.S.R. Murthy, "Experimental studies on drill penetration rate prediction in coal measure rocks through Cerchar Hardness Index tests," Journal of mines metals \& fuels, vol. 62, pp. 88-95, 2014.

[9] J. Mohammad, M. Afshari, S. Emadoddin, and R. Milad, "Experimental evaluation of hardness models by drillability tests for carbonate rocks. Journal of petroleum science and engineering," vol. 113, pp. 104-108, 2014.

[10] M. Heiniö, "Rock excavation handbook by Tamrock," Sandvik Tamrock Corp., pp. 12-45, 1999.

[11] F. Sekula, V. Krupa, and Krepelka,"Monitoring of the rock strength characteristics in the course of full of face driving process," Proceedings of the international conference on geomechanics, pp. 299-303, 1991.

[12] H.L. Hartman, "The effectiveness of indexing in percussive and rotary drilling," International journal of rock mechanics and mining sciences, vol. 3, pp. 265-78, 1966.

[13] S. Kahraman, "Rotary and percussive drilling prediction using regression analysis," International journal of rock mechanics and mining sciences, vol. 36, pp. 981-989, 1999.

[14] R.L. Schmidt, "Drillability studies - Percussive drilling in the field," USBM RI 7684, 1972 